\title{
Correspondence
}

\section{Piroxicam-induced acute renal failure (anuria)}

SIR, We report a case of piroxicam-induced acute renal failure (anuria) (ARFA) of a patient with pre-existing moderate renal failure. Although acute renal failure accompanies the use of other non-steroidal antiinflammatory drugs (NSAID), to our knowledge ARFA has not been reported with piroxicam.

A 75-year-old man with pre-existing moderate renal failure discovered in 1980 had intermittently been on methyldopa and frusemide for hypertension since 1975 . He discontinued both drugs three weeks before his admission to the hospital. He had a cerebrovascular episode without residua in 1981 . He also had congenital subluxation of his hips. Osteoarthrosis secondary to this presented in 1979 , for which he had intermittently been treated with paracetamol and sulindac. Initial laboratory data included: blood urea nitrogen: $80-95 \mathrm{mg} / \mathrm{dl}(57-68 \mathrm{mmol} / \mathrm{l})$, serum creatinine: $457 \mathrm{mmol} / \mathrm{l}$, creatinine clearance: $27.8 \mathrm{ml} / \mathrm{min}$, urine specific gravity: 1003, serum calcium: $7.5 \mathrm{mg} / \mathrm{dl}(1.9$ $\mathrm{mmol} / \mathrm{l})$, serum phosphorus: $4 \mathrm{mg} / \mathrm{dl}(1.3 \mathrm{mmol} / \mathrm{l})$, serum sodium: $125 \mathrm{mEq} / \mathrm{l}(125 \mathrm{mmol} / \mathrm{l})$, serum potassium: 3.9 $\mathrm{mEq} / \mathrm{l}(3.9 \mathrm{mmol} / \mathrm{l})$, plasma renin activity: $3.26 \mathrm{ng} / \mathrm{ml} / \mathrm{h}$. ECG and chest $x$-rays were normal. Urine cultures were negative twice. Hydration was instituted and the 24-hour urine volume increased during the first three days, but thereafter though hydration continued, the urine volume decreased and the patient became anuric on the seventh day (Fig. 1). Hydration was discontinued. The anuria (confirmed twice by bladder catheterisation) lasted for two days, but thereafter the 24-hour urine volume increased progressively and reached the preanuria levels within four days. Computerised tomography of the abdomen detected

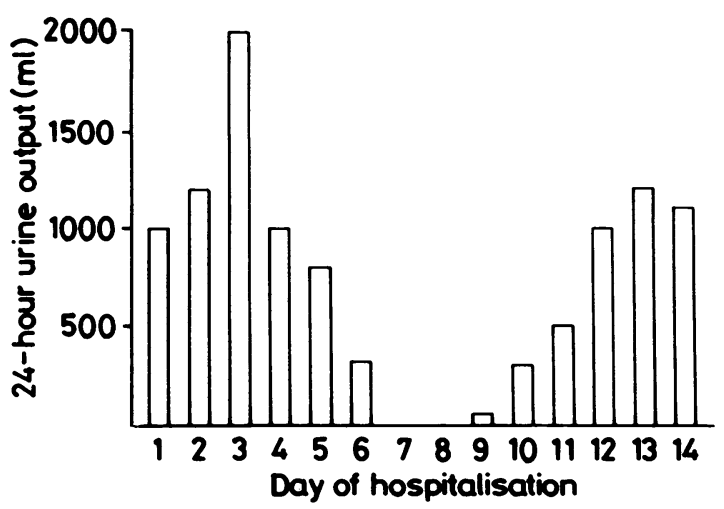

Fig. 1 Twenty-four-hour urine output during the first 14 days of the patient's hospitalisation. no abnormalities of the kidneys, ureters, or bladder, nor any abdominal masses. There was no alteration in blood 0 pressure. There was no paraproteinaemia, collagen disease, use of other drugs, or administration of contrast $\vec{\circ}$ material. During the anuria the markers of renal function were significantly impaired in comparison with the $\vec{\omega}$ preanuria state, but returned to the preanuria levels after $\sigma$ the restoration of the 24-hour urine volume above $1000 \stackrel{2}{2}$ $\mathrm{ml} / 24 \mathrm{~h}$. The anuria appeared to be attributable to the uncontrolled ingestion of piroxicam ( $30 \mathrm{mg}$ daily) by the patient himself for relief of his hip pain for the 10 days $\mathrm{c}$ before the development of anuria.

A strong association exists between piroxicam ingestion and the development of acute renal failure. 'Vasconstriction due to inhibition of vasodilator prostaglandin $E_{2}$ 의 synthesis by NSAID in patients with pre-existing renal $\rightarrow$ failure appears to precipitate acute renal failure (anuria). Other risk factors ${ }^{2}$ (hypereninaemia and hyponatraemia as in our patient) combined with the inhibition of $\vec{\bullet}$ prostaglandin synthesis may in addition precipitate acute $\infty$ renal failure (anuria). Despite the lack of a diagnostic. rechallenge for ethical reasons, the many similarities $\square$ between this patient and those reported with other NSAID $^{34}$ and the existence of the above mentioned risk factors suggest that piroxicam caused this patient's acute renal failure and anuria.

University of Athens

Medical School,

Alexandra Hospital,

Vas. Sofias-K. Lourou Str.,

GR 11528 Athens, Greece

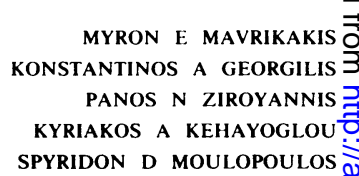

\section{References}

1 Frais A M. Burgess D E, Mitchell D L. Piroxicam induced renal failure and hyperkalemia. Ann Intern Med 1983; 99: 129-30.

2 Glive M D, Stoff S J. Renal syndromes associated with 3 nonsteroidal anti-inflammatory drugs. $N$ Engl J Med 1983; 310: 응 563-72.

3 Robertson C E. Ford M J, Van Sorensen V, Dlugolecka M $D$ Prescott L F. Mefenamic acid nephropathy. Lancet 1980; i: 232-3.

4 Thomson B, Erom A, Jacobsen I B, Starklint H, Predersen P. 으․ Acute renal failure associated with fenoprofen therapy. Arthri- N tis Rheum 1983; 26: 234

\section{Unusual case of childhood dermatomyositis}

SIR, We read with interest the letter by Foley and Payne, describing an unusual case of dermatomyositis character $\bar{\Phi}$ ised by spontaneous remissions and recurrences separate by long periods of well-being, as we observed a similar 